ScIDoC

International Journal of Dentistry and Oral Science (IJDOS)

ISSN: 2377-8075

\title{
Evaluate The Effect Of Different Irrigation Solutions During Surgical Extraction Of Impacted Lower Third Molars On Postoperative Trismus And Alveolitis
}

George alnawakil ${ }^{1}$, Yasser almudallal ${ }^{2}$, Mohamad Droubi ${ }^{1}$, Zuhair Al-Nerabieah ${ }^{3 *}$

${ }^{1}$ Department of Oral and Maxillofacial Surgery, Faculty of Dentistry, Damascus University, Syria.

${ }^{2}$ Professor, Department of Oral and Maxillofacial Surgery, Faculty of Dentistry, Damascus University, Syria.

${ }^{3}$ Paediatric dentistry department, Dental collage, Damascus University, Al-Mazzeh St. Damascus, PO Box 30621, Syria.

\section{Abstract}

Background \& Objective: postoperative trismus and alveolitis after surgical extraction of impacted third molars is the most complication that disturb thepatient. Recently many researches reported about many modifications in the techniques, methods and materials used in surgical extraction to decrease complications, one of these is using chlorehexidine and povidone iodine as irrigation solution instead of saline.

This research aim to evaluate the effectiveness ofthese tow irrigation solutions in decrease of these post surgical extraction complications compared with saline .

Methods \& Material: 30 adult patients aged between 19-25 years with tow mesial impacted third lower molars and partially bone covered (based on panoramic image).

60 molars in this study divided in three group ,group I where irrigant used was povidone iodine $0.5 \%$, group II as chlorhexidine $0.02 \%$, and group III as saline $0.9 \%$.

Trismus was monitored by measuring the mouth opening before operation , 3 days later and after one week .Alveolitis cases were recorded by examining all patients on the third day .

Results: According to ANOVA test. Trismus was significantly moreon third day in group I and group III than in group II $(\mathrm{P}<0.01)$ and less clearly on seventh day. So the results came in favor of Chlorehexidine compared to another irrigation solutions. One alveolitis case was reported in group I and group III ,nilin group II and no statistically significant differences $(\mathrm{p}>0.01)$

Conclusion: The results were following that Chlorehexidine go one better than Povidone iodine and Saline in decreasing trismus after impacted lower third molars surgical extraction. There is no clear relationship between the type of irrigation solution and the occurrence of alveolitis.

Keywords: Impacted Third Molars; Surgical Extraction; Irrigation Solutions; Chlorehexidine; Povidone Iodine; Trismus; Alviolitis.

\section{Introduction}

Extraction of the lower third molar is one of the most common surgeries in dental clinic. Several complaints occur after surgery, the most important of which is trismus and alveolitis. Trismusis defined as the inability to open the mouth as a result of a limitation in the work of the masseter muscles, It occurs as aresult of trauma and the post-operative inflammatory process [1], reaches its maximum on the third day, and then recedes until the seventh day [2].

Alveolitis known as failed to form the blood clot or dissolve it before replacing it with a granular tissue within the natural healing pathway and is not associated with infection [3]. Pretending to be dull, pulsating pain moderate to severe and spread to the ear without the signs and symptoms usually seen in infection such as swelling, redness and fever. We notice the presence of an empty alveolar cavity with a partial or complete disappearance of the blood clot and exposed bone walls, and this exposed bone is the

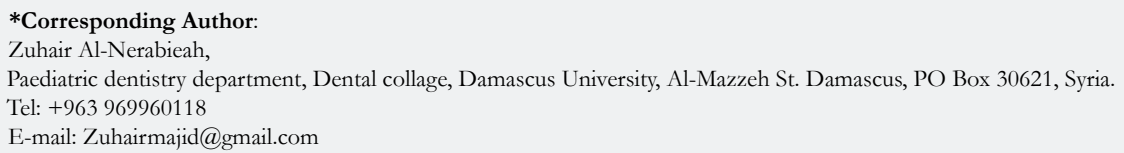

Copyright: Zuhair Al-Nerabieah 2021 . This is an open-access article distributed under the terms of the Creative Commons Attribution License, which permits unrestricted use, distribution and reproduction in any medium, provided the original author and source are credited. 
source of pain. it begins to appear on the third day or the fourth and usually associated with an unpleasant smell and taste [4].

The importance of using irrigation solutions comes through removing the bone cutting products, cleaning the socket, cooling the bone cutting site, and providing a clear vision for the surgeon. The normal saline is most commonly recommended as the best cleansing solution for human body wound [5]. povidone-iodine is a mixture of Povidone and iodine with short acting but widespectrum bactericidal effects, sporicidal, fungicidal and virucidal activity [6]. This irrigant has antiseptic properties and has a significant effect in reducing the level of infection in the context of surgery $[7,8]$. In dental surgery, povidone iodine is used mainly to irrigationsocket after extraction [9]. Chlorhexidine is a bacteriostatic agent from the biguanidfamily. It is effective against a broad bacterial spectrum that includes positive and gram-negative bacteria, several strains of fungi and some types of viruses [10].

The aim of this study is evaluation the effectiveness of saline $0.9 \%$, povidone iodine $0.5 \%$, and chlorhexidine $0.02 \%$ irrigating solutions on trismus, and alviolitis after surgical removal of lower third molars.

\section{Materials and Methods}

30 patients were involved in this study requiring the surgical extraction of tow mandibular third molars. Agreementwas obtained from the local ethical committee for the randomized controlled clinical trial, and all patients signed the informed consent form of the study. Inclusion criteria were, non smoking healthy patients without any systemic problems, not taking any medication and not allergic to any substance or agent to be used in the surgical extraction, patients' age range from 19-25 years with similarly placed bilateral impacted lower third molars indicated for surgical extraction, the angulation of the molars was misoangular [11] with partial bone coverd [12] (according to panoramic image), the working time for each molar extraction range from 30-40 minutes. 60 molars were randomly divided into three groups $(n=20)$. The irrigantion solutions used in these groups werepovidone iodine $0.5 \%$ in group I, chlorhexidine gluconate $0.02 \%$ in group II, andnormal saline $0.9 \%$ in group III, So that a different irrigant is used for each molar in each patient (split mouth technique).

\section{Extraction protocol}

Extraoral disinfectant with povidone iodine and intraoral rinsing with chlorhexidine were performed. Inferior alveolar nerve block, lingual and buccal nerves' local anesthesia were done with $2 \%$ lidocaine and 1:80000 adrenaline. A sulcular incision from the mesial of the second molar continued distally to obtain a mucoperi- osteal invelope flap. Bone removal was done with S.S bur under profuse irrigation as per the assigned group.After extraction, copious irrigation with the specified irrigant for wound debridement. Interrupted suture with 3-0 were done. The same steps were repeated on the opposite side after 3 weeks in each patient. Patients were prescribed oral antibiotic (augmentine $1000 \mathrm{mg}$ twice a day for 5 days) and oral analgesic (paracetamol 1000mg every 6 hours as needed).Patients were instructed for avoid taking any medication without telling the researcher, gargling during first 24 hours, eatinghard diet, brushing and flossing around the surgical site for a week.Suture removed on seventh day.

All the patients were reviewed on third and seventh daypost surgery to evaluate trismus and examine the extraction site for the presence of alveolar osteitis, To evaluate trismus a single examiner performed all clinical measurements prior to surgery (baseline) and on third and seventh day postoperatively.

A millimeter ruler was used to take the maximum mouth opening measurement between tow marking points, the first is in the middle of the incisal edge of the right uppercentral incisor and the second is in the middle of the right lower central incisor. Difference between the measurements taken postoperatively on third and seventh day and the baseline value was regarded as the theamoumt of trismus of that day.

\section{Results}

A total of 30 patients requiring surgical removal of bilaterally impacted mandibular third molars were included in this study of whom 8 were males and 22 females with a mean age of 22.8 years (range 19-25 years).

Trismus was evaluated using ANOVA test. Statistically significant difference was found between the three groups on third day but no statistically significant difference on seventh day [table 1]. And to know which groups differ from others, Bonferroni test was made which resulted in maximum mouth opening was better in Group II as compared to Group I and III ( $<<0.01)$ [table 2].

Alveolitis was observed in one case in both groups I and III and nil in group II. According to chi square test no significant difference was observed between the three groups ( $\mathrm{P}>0.01)$ [table 3].

\section{Discussion}

Extraction of the lower third molar is one of the most common surgeries in dental clinic, many complaints occur after surgery, the most important of which is trismus and alveolitis. This study was

Table 1. Evaluation of postoperative trismus on day 3 and 7, according to ANOVA test p-value was significant on third day.

\begin{tabular}{|c|c|c|c|c|}
\hline Time period & Group & Number of cases & Mean of trismus m.m & P-VALUE \\
\hline \multirow{3}{*}{ Third day } & Group I & 20 & 17.05 & \multirow{3}{*}{$0.0003^{*}$} \\
\cline { 2 - 4 } & Group II & 20 & 11.6 & \\
\cline { 2 - 4 } & Group III & 20 & 17.1 & \multirow{3}{*}{0.017} \\
\hline \multirow{3}{*}{ Seventh day } & Group I & 20 & 4.85 & \\
\cline { 2 - 4 } & Group II & 20 & 2.35 & \\
\cline { 2 - 4 } & Group III & 20 & 5.15 & \\
\hline
\end{tabular}


Table 2. Bonferroni test showed that the differences were significantwhen comparing group I with II and group III with II.

\begin{tabular}{|c|c|c|c|}
\hline group (I) & group (J) & $\begin{array}{c}\text { difference } \\
\text { between (I-J) }\end{array}$ & p-value \\
\hline Group I & Group II & 5.45 & $0.008^{*}$ \\
\hline Group I & Group III & -0.05 & 1 \\
\hline Group II & Group III & -5.5 & $0.007^{*}$ \\
\hline
\end{tabular}

Table 3: Chi square tast showed that no significant difference was observed between groups.

\begin{tabular}{|c|c|c|c|}
\hline Group & Alveolitis cases & Chi square & P-VALUE \\
\hline Group I & 1 & \multirow{3}{*}{1.034} & \multirow{2}{*}{0.596} \\
\cline { 1 - 2 } Group II & 0 & & \\
\cline { 1 - 2 } Group III & 1 & & \\
\hline
\end{tabular}

designed to evaluate the efficacy of saline, povidone iodine, and chlorhexidine on postoperative complaints.

The role of systemic antibiotics in surgical removal of third molars is limited due to deficiency ofsufficientspectrum to cover potential intraoral bacteria and inability to reach to an effective level in saliva(13), hence the important role that irrigants play. The importance in postoperative complaints in terms of removing foreign bodies anddevitalised tissue that act as haven for bacteria and cover them from the body's defences(14).Another important role that irrigants play is to decrease the bacterial contaminationof socket, the microbial load, debridement of devitalized tissueand so very necessity for the healing processduring and after surgical procedures(15).

Normal saline is most commonirrigant used for impacted teeth surgery and it is recommended as the best cleansing solution for human body wound.

povidone-iodine is a mixture of povidone and iodine, has a widespectrum bactericidal effects and has a significant effect in reducing the level of infection and the oral cavity bacterial counts up in the context of dental surgery. In lower concentrations, it inhibits leucocyte chemotaxis while retaininig its antiseptic properties upto dilution of $0.1 \%(16)$.

Chlorhexidine is recognized as antiseptic and has been revealed to be safe and effective againsta broad bacterial spectrum that includes gram-positive and gram-negative bacteria, several strains of fungi and some types of viruses.It is classified as one of the compounds affecting the bacterial cell wall and its effect varies according to the concentration and bacterial type, as in low concentrations its effect is bacteriostatic, while in high concentrations, it has a bactericidal effect(17). In addition, chlorhexidine has the advantage of residual effect over 48 hours, providing longer duration of action.In contrast with povidone iodine its antimicrobial activity is not influenced by existence of body fluids such as $\operatorname{blood}(18)$.

In the present study, it was found that the $0.02 \%$ chlorhexidine was more effective than other irrigantsin reducing the amount of trismus ,but there is no clear influence in control of alveolitis. According to this study, it was found that profuse irrigation, removal of all foreign bodies from socket, bone cooling and the ability to maintain a high level of disinfection and the selection of healthy and non-smoking patients has played an important role in reducing the number of alveolitis cases more than the irrigants type itself.

Other studies may be required to know the different effects of other concentrations of irrigants and what role they play in other kinds of patients, such as immunecompromisedor diabetic patients.

\section{Conclusion}

Under the conditions of the present study, $0.02 \%$ chlorhexidine was found more effective than $0.5 \%$ povidone iodine and $0.09 \%$ saline in control of postoperative trismus following the removal of impacted lower third molars, while the incidence of alveolitis was not affected by the type of irrigan.

\section{References}

[1]. Santiago-Rosado LM, Lewison CS. Trismus.2018.

[2]. Hupp JR. Legal implications of third molar removal. Oral Maxillofac Surg Clin North Am. 2007 Feb 1;19(1):129-36.

[3]. Hedström L, Sjögren P. Effect estimates and methodological quality of randomized controlled trials about prevention of alveolar osteitis following tooth extraction: a systematic review. Oral Surg Oral Med Oral Pathol Oral Radiol Endod. 2007 Jan;103(1):8-15.Pubmed PMID: 17178488.

[4]. Blum IR. Contemporary views on dry socket (alveolar osteitis): a clinical appraisal of standardization, aetiopathogenesis and management: a critical review. Int J Oral Maxillofac Surg. 2002 Jun;31(3):309-17.Pubmed PMID: 12190139.

[5]. Lawrence JC. Wound irrigation. J Wound Care. 1997 Jan 2;6(1):23-6.

[6]. Fleischer W, Reimer K. Povidone-iodine in antisepsis--state of the art. Dermatology. 1997;195 Suppl 2:3-9.Pubmed PMID: 9403248.

[7]. Chundamala J, Wright JG. The efficacy and risks of using povidone-iodine irrigation to prevent surgical site infection: an evidence-based review. Can. J. Surg. 2007 Dec;50(6):473-81.

[8]. Kirby JP, Mazuski JE. Prevention of surgical site infection. Surg Clin North Am . 2009 Apr 1;89(2):365-89.

[9]. Kumar BP, Maddi A, Ramesh KV, Baliga MJ, Rao SN, Meenakshi. Is povidone-iodine a hemostyptic? A clinical study. Int J Oral Maxillofac Surg. 2006 Aug;35(8):765-6.Pubmed PMID: 16777382.

[10]. Holloway PM, Bucknall RA, Denton GW. The effects of sub-lethal concentrations of chlorhexidine on bacterial pathogenicity. J. Hosp. Infect. 1986 Jul 1;8(1):39-46.

[11]. Pell GJ, Gregory GT. Report on a ten-year study of a tooth division technique for the removal of impacted teeth. Am J Orthod Oral Surg. 1942 Nov 1;28(11):B660-6.

[12]. Gbotolorun OM, Olojede AC, Arotiba GT, Ladeinde AL, Akinwande JA, Bamgbose BO. Impacted mandibular third molars: presentation and post- 
operative complications at the Lagos University Teaching Hospital. Nig Q J Hosp Med. 2007 Jan-Mar;17(1):26-9.Pubmed PMID: 17688169.

[13]. Urvi S, Haren P, Hiren P, HITESH D. EFFICACY OF CHLORHEXIDINE VERSUS BETADINE AS AN IRRIGATING AGENT DURING REMOVAL OF BILATERAL IMPACTED LOWER THIRD MOLARS. Pak Oral Dental J . 2014 Jun 1;34(2):4.

[14]. Peterson LJ. Peterson's principles of oral and maxillofacial surgery. PMPHUSA; 2012:1621.

[15]. Bowler PG, Duerden BI, Armstrong DG. Wound microbiology and associated approaches to wound management. Clin. Microbiol. Rev. $2001 \mathrm{Apr}$ $1 ; 14(2): 244-69$.
[16]. Zamora JL. Chemical and microbiologic characteristics and toxicity of povidone-iodine solutions. Am J Surg. 1986 Mar;151(3):400-6.Pubmed PMID: 3513654 .

[17]. Jayaprakash K, Veeresha KL, Hiremath SS. A comparative study of two mouthrinses on plaque and gingivitis in school children in the age group of 13-16 years in Bangalore city. J Indian Soc Pedod Prev Dent. 2007 JulSep;25(3):126-9.Pubmed PMID: 17951928.

[18]. Larsen PE. The effect of a chlorhexidine rinse on the incidence of alveolar osteitis following the surgical removal of impacted mandibular third molars. J. Oral Maxillofac. Surg. 1991 Sep 1;49(9):932-7. 